\title{
Age related susceptibility to Campylobacter jejuni infection in a high prevalance population
}

\author{
N J RICHARDSON, H J KOORNHOF, V D BOKKENHEUSER, Z MAYET, AND E U ROSEN
}

Emergent Pathogen Research Unit, South African Medical Research Council; School of Pathology, South African Institute for Medical Research, and the University of the Witwatersrand, Johannesburg; Department of Microbiology, St Luke's-Roosevelt Hospital Centre, New York; and Department of Paediatrics, Baragwanath Hospital, Johannesburg

SUMMARY In a year long prospective study of diarrhoea in children under 2 years of age in Soweto, South Africa, Campylobacter jejuni was isolated in 18 of 60 children under 9 months of age with diarrhoea, compared with 4 of 60 age matched controls. In the older children, 16 of 51 children with diarrhoea and 17 of 51 control children excreted this organism in their faeces. These results indicate a change in susceptibility to $C$ jejuni in children over 9 months of age. Campylobacter enteritis in the young children was usually mild, without macroscopic blood in the faeces, and prolonged excretion of the organism after acute attacks was not infrequent. Breast feeding did not seem to protect against colonisation with $C$ jejuni.

In developing countries intestinal Campylobacter jejuni infections are common in young children. ${ }^{1-8}$ In studies in Zaire, ${ }^{14}$ Ruanda, ${ }^{2}$ South Africa, ${ }^{3}$ Bangladesh, ${ }^{5}$ and the Gambia $^{7}$ an important association between the presence of $C$ jejuni in the stool and diarrhoea has been shown. In the South African study $C$ jejuni was isolated in $32 \%$ of infants less than 9 months old with diarrhoea compared with $4 \%$ of controls. In contrast, in children 9-24 months old the isolation of $C$ jejuni was similar in the faeces of children with diarrhoea and controls. ${ }^{3}$ These findings prompted us to reinvestigate more critically the age at which children convert from a diarrhoea susceptible to a diarrhoea refractory response to $C$ jejuni in the intestinal tract. We investigated concurrently the duration of excretion of $C$ jejuni after acute attacks of diarrhoea and evaluated the protective effect of breast feeding on the outcome of infection. We also noted the main clinical features of $C$ jejuni associated enteritis and investigated the aetiological role of other bacterial pathogens in diarrhoea in these children.

\section{Materials and methods}

Patients. Clinical data on 111 children with diarrhoea admitted to the Baragwanath Hospital near Johannesburg were recorded. Stool specimens were obtained for culture and processed within 4 hours of admission. Mothers of babies in whom $C$ jejuni was isolated were asked to bring them back 3 weeks later for further stool examination. Children with positive stool cultures on this occasion were checked weekly until negative results were obtained.

Controls. Within 24 hours each patient with diarrhoea was matched for age and sex with a control baby. These apparently healthy babies came with their mothers to family planning or childcare clinics. We excluded children who had suffered any illness, including diarrhoea, within the previous 2 weeks. Information on feeding was recorded. Faeces were collected from the napkins, transported to the laboratory in Johannesburg, and processed within 4 hours.

Media and bacteriological techniques. Three media were used for the isolation of $C$ jejuni. The composition per litre medium was:

BCA - 39 g Columbia agar base (Oxoid Ltd. Basingstoke, England) and $100 \mathrm{ml}$ citrated horse blood; BCHA-31 g cysteine heart agar (Difco Laboratories, Detroit, USA), $100 \mathrm{ml}$ citrated horse blood, $5 \mathrm{mg}$ novobiocin (Upjohn, Kalamazoo, Michigan, USA), and $1.0 \mathrm{ml} 0.5 \%$ brilliant green in distilled water ${ }^{9}$; and Skirrow's medium ${ }^{10}-40 \mathrm{~g}$ oxoid blood agar base No 2, 50-70 ml lysed horse blood, $10 \mathrm{mg}$ vancomycin, $2500 \mathrm{IU}$ polymyxin B sulfate, and $5 \mathrm{mg}$ trimethoprim lactate (Oxoid Ltd). 
Skirrow's medium was streaked directly with a loopful of faeces and incubated at $42^{\circ} \mathrm{C}$. In addition, all 3 media were seeded with $0.2 \mathrm{ml}$ each of a filtrate prepared as described ${ }^{311} 12$ and incubated at $37^{\circ} \mathrm{C}$. All media were incubated in an atmosphere of $10 \% \mathrm{CO}_{2}, 18 \% \mathrm{O}_{2}$, and $72 \% \mathrm{~N}_{2}{ }^{3}$ for 48 hours. Colonies morphologically resembling $C$ jejuni were picked, subcultured, and identified according to Holdeman et al. ${ }^{13}$ Thermoresistance, sensitivity to nalidixic acid, hippurate hydrolysis, ${ }^{14}$ and $\mathrm{H}_{2} \mathrm{~S}$ production $^{15}$ were used for identification and biotyping of isolates.

Conventional techniques were used for the isolation and identification (including serotyping) of salmonellas and shigellas. Five Escherichia coli colonies per sample of faeces were tested for antigens associated with enteropathogenicity (EPEC) by using commercially available EPEC antisera (Hoechst, Behring-Werke, Germany; Wellcome Research Reagents, England), for enteroinvasiveness by Sereny's test (EIEC), and for both heat stabile and heat labile enterotoxin strains (ETEC) as described by Robins-Browne et al. ${ }^{16}$

\section{Results}

Recovery of bacterial pathogens from stool specimens. $C$ jejuni was isolated from $31 \%$ of children with diarrhoea regardless of their age group (Table 1) and in $19 \%$ of the controls. It was the sole pathogen in $15 \%$ and $14 \%$ respectively in the diarrhoea and control groups. The 13 isolates available for biotyping with hydrolysed hippurate belonged, with 1 exception, to biotype 1 .

The incidence of salmonellas and shigellas was $4 \%$ or less in all groups. EPEC strains were recovered from $43 \%$ of children with diarrhoea and from $23 \%$ of controls $(P<0 \cdot 01)$. ETEC strains of $E$ coli were detected in 12 patients with diarrhoea and 5 controls. No EIEC were found.

Age specific faecal excretion of $C$. jejuni. There was a statistically significant difference $(P<0.01)$ between the isolation rate of $C$ jejuni from infants with diarrhoea and from controls up to age 8 months (Table 2). This was also true when children excreting $C$ jejuni as the sole bacterial pathogen were considered $(P<0 \cdot 02)$. This trend changed conspicuously once children reached the age of 9 months, and between 1 and 2 years of age there was a steady decline in number of children with $C$ jejuni associated diarrhoea. In contrast, in the control group the incidence of $C$ jejuni in the faeces increased markedly after 9 months of age. The finding of fewer cases of $C$ jejuni associated diarrhoea after age 1 year coincides with a general decline in the number of patients in this age group admitted to hospital with diarrhoea.

Table 1 Faecal excretion of Campylobacter jejuni and other bacterial pathogens in Sowetan children

\begin{tabular}{|c|c|c|c|c|c|c|}
\hline Group & $\begin{array}{l}\text { Age } \\
\text { (Months) }\end{array}$ & No & $\begin{array}{l}\text { C jejunias } \\
\text { sole bacterial } \\
\text { pathogens }\end{array}$ & $\begin{array}{l}\text { C jejuni plus } \\
\text { other bacterial } \\
\text { pathogens* }\end{array}$ & $\begin{array}{l}\text { Bacterial pathogens } \\
\text { other than } \\
\text { C jejuui* }\end{array}$ & $\begin{array}{l}\text { No bacterial } \\
\text { pathogens }\end{array}$ \\
\hline \multirow[t]{2}{*}{ Diarrhoea } & $\begin{array}{l}0-8 \\
9-24\end{array}$ & $\begin{array}{l}60 \\
51\end{array}$ & $\begin{array}{r}10 \\
7\end{array}$ & $\begin{array}{l}8 \\
9\end{array}$ & $\begin{array}{l}21 \\
11\end{array}$ & $\begin{array}{l}21 \\
24\end{array}$ \\
\hline & Total & 111 & 17 & 17 & 32 & 45 \\
\hline \multirow[t]{2}{*}{ Controls } & $\begin{array}{l}0-8 \\
9-24\end{array}$ & $\begin{array}{l}60 \\
51\end{array}$ & $\begin{array}{r}1 \\
14\end{array}$ & $\begin{array}{l}3 \\
3\end{array}$ & $\begin{array}{r}16 \\
2\end{array}$ & $\begin{array}{l}40 \\
28\end{array}$ \\
\hline & Total & 111 & 15 & 6 & 18 & 68 \\
\hline
\end{tabular}

*Mainly enteropathogenic Escherichia coli; some children harboured 2 or more pathogens.

Table 2 Age specific faecal excretion of Campylobacter jejuni

\begin{tabular}{|c|c|c|c|c|c|c|}
\hline Age group (months) & $<4$ & $5-8$ & $9-12$ & $13-16$ & $17-20$ & $21-24$ \\
\hline No investigated* & $2 \times 24$ & $2 \times 36$ & $2 \times 20$ & $2 \times 12$ & $2 \times 14$ & $2 \times 5$ \\
\hline $\begin{array}{l}\text { Total } C \text { jejuni isolations } \\
\text { Diarrhoeal patients, No (\%) } \\
\text { Controls, No (\%) }\end{array}$ & $\begin{array}{l}9(38) \\
3(13)\end{array}$ & $\begin{array}{l}9(25) \\
1(3)\end{array}$ & $\begin{array}{l}8(40) \\
7(35)\end{array}$ & $\begin{array}{l}2 \text { (17) } \\
7 \text { (33) }\end{array}$ & $\begin{array}{l}5(36) \\
4(29)\end{array}$ & $\begin{array}{l}1(20) \\
2(40)\end{array}$ \\
\hline $\begin{array}{l}C \text { jejuni as sole pathogen } \\
\text { Diarrhoeal patients, No }(\%) \\
\text { Controls, No }(\%)\end{array}$ & $\begin{array}{l}6(25) \\
0(0)\end{array}$ & $\begin{array}{l}4(11) \\
1 \text { (3) }\end{array}$ & $\begin{array}{l}5(25) \\
6(30)\end{array}$ & $\begin{array}{ll}1 & (8) \\
3 & (25)\end{array}$ & $\begin{array}{ll}1 & (7) \\
3 & (21)\end{array}$ & $\begin{array}{l}0(0) \\
2(40)\end{array}$ \\
\hline
\end{tabular}

*The diarrhoea and control groups were equally matched and the numbers are expressed as $2 \times$ the number of each of the respective matched groups. 
Table 3 Effect of breast feeding on Campylobacter jejuni associated diarrhoea among $\leqslant 8$ months old children

\begin{tabular}{llllll}
\hline Group & \multicolumn{2}{l}{ Wholly/partially breast fed } & & \multicolumn{2}{l}{ Bottle fed } \\
\cline { 2 - 3 } \cline { 5 - 6 } & Total & $\begin{array}{c}\text { C jejuni } \\
\text { infected }\end{array}$ & & Total & $\begin{array}{c}\text { Cjejuni } \\
\text { infected }\end{array}$ \\
\hline $\begin{array}{c}\text { Diarrhoea } \\
(\mathrm{n}=31) \dagger\end{array}$ & 16 & 5 & 15 & 5 \\
$\begin{array}{c}\text { Controls } \\
(\mathrm{n}=41) \dagger\end{array}$ & 32 & 1 & 9 & 0 \\
\hline
\end{tabular}

* Only children excreting $C$ jejuni as sole pathogen are included. †Excludes children infected with intestinal pathogens other than C jejuni.

Clinical picture. The clinical picture of $C$ jejuni diarrhoea in our investigation was relatively mild: bloody stools, shock, acidosis, and hyperpyrexia were rare. Moderate dehydration was, however, common and moderate malnutrition was frequent especially among weaned children. Few of the younger and most of the older children had suffered earlier attacks of gastroenteritis. Clinical recovery was generally fast and most children were discharged home in 7 days without specific antimicrobial treatment.

Breast feeding. Patients aged up to 8 months old in whom $C$ jejuni was the only bacterial pathogen isolated were investigated for the protective effect of partial or complete breast feeding. Table 3 shows that breast feeding did not prevent colonisation with $C$ jejuni. Considering infants aged up to 8 months old as a group, a similar analysis (not tabulated) revealed that 31 of 60 infants with diarrhoea and 46 of 60 control infants were breast fed, indicating that breast feeding prevents some cases of diarrhoea caused by agents other than $C$ jejuni $(\mathrm{P}<0 \cdot 01)$.

$C$ jejuni excretion after acute gastroenteritis. Eleven children with diarrhoea excreted $C$ jejuni from 3 to 12 weeks and 1 for at least 40 weeks. After the acute attack, faecal samples from this patient were examined weekly from week 3 to week 10 and then fortnightly for the next 10 weeks. The organism was isolated on all but 2 occasions and mixed infections with EPEC, salmonellas, or shigellas were observed 7 times. Diarrhoea occurred during week 15 and week 29 and at the last episode the baby was treated with erythromycin for 5 days. The diarrhoea subsided, faeces were negative for $C$ jejuni 5 weeks later, but the organism reappeared in week 40 . Control babies were not available for follow up cultures. As the isolates from these children were not serotyped at the time we do not know to what extent reinfection played a role in the prolonged recovery of $C$ jejuni from their faeces.

\section{Discussion}

These findings strongly reinforce earlier observations that $C$ jejuni infection is widespread in black Sowetan children. ${ }^{3}$ They also confirm that faecal excretion of the organism in early infancy $(<9$ months of age) is almost always associated with diarrhoea $(P<0.01)$. The evidence for an aetiological role for $C$ jejuni in these infants' illness is further substantiated when the children in whom $C$ jejuni was the sole observed pathogen are considered. Again the difference between the diarrhoea and control groups is statistically significant $(\mathrm{P}<0.02)$.

The decline in $C$ jejuni associated diarrhoea observed with increasing age occurred despite the persistently high excretion rates of $C$ jejuni in the $>9$ months age group (Table 2). The same trend was observed in Bangladesh where a $2 \%$ random sample of patients at a 'diarrhoea hospital' showed a decline in the isolation rates of $C$ jejuni in children with diarrhoea from $21 \%$ in infants under 1 year of age to $9.5 \%$ in patients aged between 1 and 2 years. ${ }^{5}$

Why many older children in Soweto and developing countries do not develop diarrhoea while harbouring $C$ jejuni is not clear. Earlier studies in the Sowetan community indicated a high exposure of families to $C$ jejuni through eating chicken, which is the cheapest meat available to them, and their custom of keeping fowls in their backyards. Bovine intestine is also a cheap and popular source of food while many families keep pet dogs that are commonly fed on poultry scraps. We isolated $C$ jejuni in 26 of $30(86 \%)$ samples of fowl faeces, 4 of $30(13 \%)$ samples of bovine intestine, and 12 of $33(36 \%)$ of dog faeces collected in Soweto. ${ }^{17}$ In a controlled study in Sweden an association between the preparation and consumption of chicken and campylobacter enteritis was shown. ${ }^{18}$ In the Swedish study sick pets transmitted the disease to 2 patients and 3 definite instances of secondary cases were noted. We also found household spread of $C$ jejuni in Soweto and have recently observed repeated reinfections of different serotypes of $C$ jejuni in Sowetan children who excrete $C$ jejuni for prolonged periods (unpublished data). The extensive exposure of this population to $C$ jejuni may well hold the key to the development of resistance to clinically manifested infections in older children.

The episodes of diarrhoea in our infants excreting $C$ jejuni were only moderately severe and the 
absence of frank blood in their stools was unexpected, although variable results on the prevalence of this feature have been reported in the published reports. ${ }^{19-21}$ Data from Britain ${ }^{22}$ suggest that blood in the stools of infants aged from 1 month to 1 year may be appreciably less common than in older patients. ${ }^{19}$

The apparent lack of protection given by breast feeding against $C$ jejuni colonisation in young infants needs further investigation. The numbers in this study were small and it would be premature to deny a role for specific IgA in the prevention of diarrhoea caused by this organism. Bactericidal antibodies actively produced after infection ${ }^{20}$ may, however, be more important than those passively acquired through mother's milk. The nature of host resistance resulting in subclinical and asymptomatic infections needs elucidation and apart from immunological mechanisms competition for, or changes in receptor sites, and other factors affecting intestinal epithelial cell physiology may be responsible.

We thank Dr E Hartman for her contribution in the clinical evaluation of patients, the invaluable assistance of Sister $Z$ Khumalo, and Sister $J$ Lebogang in collecting the faecal specimens and of Mr U Mithal, Miss B Nash, Mrs A Taubin, Miss C Still, and Miss M Miliotis for technical assistance.

\section{References}

1 Butzler JP. Related vibrios in Africa (letter). Lancet 1973 ; ii: 858.

2 De Mol P, Bosmans E. Campylobacter enteritis in Central Africa (letter). Lancet 1978; i: 604.

3 Bokkenheuser VD, Richardson NJ, Bryner JH, et al. Detection of enteric campylobacteriosis in children. J Clin Microbiol 1979; 9: 227-32.

4 De Mol P, Brasseur D, Lauwers S, Zissis G, Butzler JP. Campylobacter-an important enteropathogen in a tropical area. Presented at the 20th Interscience Conference on Antimicrobial Agents and Chemotherapy, September 22-24, 1980, New Orleans. Washington, DC: American Society for Microbiology, 1980.

5 Blaser MJ, Glass RI, Huq MI, Stroll B, Kibriya GM, Alim ARMA. Isolation of campylobacter fetus ssp jujuni from Bangladeshi children. J Clin Microbiol 1980; 12: 744-7.

6 Berry RJ, Gracey M, Bamford VW. Campylobacter jejuni carriers in Australian' Aboriginal communities (letter). Med J Aust 1981; 1 : 381.

7 Billingham JD. Campylobacter enteritis in the Gambia. Trans $R$ Soc Trop Med Hyg 1981 ; 75 : 641-4.

8 Prasanna Rajan D, Mathan VI. Prevalence of campylobacter fetus subsp jejuni in healthy populations in Southern India. J Clin Microbiol 1982; 15: 749-51.

9 Florent A. Méthode d'isolément de vibrio foetus á partir d'enchantillons polymicrobiens spécialement du liquide préputial milieu sélectif 'coeur-sang-gélose au vert brillant' en microaérobiose. Soc Biol 1956; 150: 1059-61.

10 Skirrow MB. Cambylobacter enteritis: a 'new disease'. Br Med J 1977; ii: 9-11.

11 Dekeyser P, Gossuin-Detrain M, Butzler JP, Sternon J. Acute enteritis due to related vibrio: first positive stool cultures. J Infect Dis 1972;125: 390-2.

12 Butzler JP, Dekeyser P, Detrain M, Dehaen F. Related vibrio in stools. J Pediatr 1973; 82: 493-5.

13 Holdeman LV, Cato EP, Moore WEC, eds: Anaerobe laboratory manual. 4th ed. Blacksburg: Virginia Polytechnic Institute and State University, 1977: 114-5.

14 Harvey SM. Hippurate hydrolysis by campylobacter fetus. J Clin Microbiol 1980; 11 : 435-7.

15 Skirrow MB, Benjamin J. Differentiation of enteropathogenic campylobacter (letter). J Clin Path 1980; 33: 1122.

16 Robins-Browne RM, Still CS, Miliotis MD, et al. Summer diarrhoea in African infants and children. Arch Dis Child 1980; 55: 923-8.

17 Richardson NJ, Koornhof HJ. Campylobacter infections in Soweto. S Afr Med J 1979; 55: 73-4.

18 Norkrans G, Svedhem A. Epidemiological aspect of campylobacter jejuni enteritis. J Hyg Camb 1982; 89: 163-70.

19 Anonymous. Campylobacter infection in Britain, 1977. Br Med J 1978; i: 1357.

20 Karmali MA, Fleming PC. Campylobacter enteritis in children. J Pediatr 1979; 94: 527-33.

21 Pai CH, Sorger S, Lackman L, Sinai RE, Marks I. Campylobacter gastroenteritis in children. $J$ Pediatr 1979;94: 589-91.

22 Blaser MJ, Berkowitz ID, LaForce FM, Cravens J, Reller LB, Wang WL. Campylobacter enteritis. Clinical and epidemiologic features. Ann Intern Med 1979; 91 : $179-85$.

Correspondence to Professor H J Koornhof, Department of Microbiology, The South African Institute for Medical Research, PO Box 1038, Johannesburg 2000, Republic of South Africa.

Received 5 May 1983 